\title{
Potential of Baccharis alnifolia Meyen \& Walpan (Chilka) from northern Chile used as a medicinal infusion
}

\section{Emilio Soto ${ }^{1}$ Luis Bustos ${ }^{2}$ (D) Mario Juan Simirgiotis ${ }^{3}$ (D) Claudio Parra $^{1^{*}}$ (D)}

\author{
${ }^{1}$ Laboratorio de Productos Naturales y Química Medica, Facultad de Ciencias Agronómicas, Universidad de Tarapacá, 1000000, Arica, Chile. \\ E-mail: cparra@uta.cl. "Corresponding autor. \\ ${ }^{2}$ Escuela de Medicina, Facultad de Ciencias de la Salud, Universidad de Tarapacá, Arica, Chile. \\ ${ }^{3}$ Instituto de Farmacia, Facultad de Ciencias, Universidad Austral de Chile, Valdivia, Chile.
}

\begin{abstract}
Baccharis alnifolia Meyen \& Walp. is a native and medicinal, Chilean Altiplano herb that is used as a poultice and also consumed as an infusion to relieve inflammation. This study evaluated the antioxidant and cytotoxic effect of the ethanolic extract of B. alnifolia and their infusion. It was reported that the ethanol extract contains $4.42 \mathrm{mg} G A E / g$ of dry weight and the infusion contains $35.86 \mathrm{mg} G A E / L$ of total polyphenols. Also, it determined the antioxidant capacity using Ferric reducing antioxidant power (FRAP), Oxygen Radical Absorbance Capacity (ORAC) and Trolox equivalent antioxidant capacity (TEAC) assay. Moreover, seven metabolites including between phenolic acids and flavonoids were identified for the first time in both extracts of the medicinal plant Baccharis alnifolia. The UHPLC-DAD chromatograms revealed the majority presence of ferulic acid and luteolin, both could be responsible for the antioxidant and cytotoxic activity. Furthermore, we realized a preliminary screening of cytotoxicity in different tumor cell lines, finding that these extracts have cytotoxic potential on kidney cells. Key words: Antioxidant activity, Baccharis alnifolia, Bioactivity, Medicinal plant, UHPLC-DAD.
\end{abstract}

Potencial de Baccharis alnifolia Meyen \& Walpan (Chilka) do norte do Chile usado como infusão medicinal

RESUMO: Baccharis alnifolia Meyen \& Walp. é uma erva altiplana nativa e medicinal, chilena que é usada como cataplasma e também consumida como uma infusão para aliviar a inflamação. Este estudo avaliou o efeito antioxidante e citotóxico do extrato etanólico de B. alnifolia e sua infusão. Verificou-se que o extrato etanólico contém 4,42 $\mathrm{mg} \mathrm{GAE} \mathrm{/} \mathrm{g}$ de peso seco e a infusão contém 35,86 mg GAE / L de polifenóis totais. Além disso, determinou a capacidade antioxidante utilizando o poder antioxidante redutor de Fração (FRAP), Capacidade de Absorção Radical de Oxigênio (ORAC) e capacidade antioxidante equivalente de Trolox (TEAC). Além disso, sete metabólitos, entre ácidos fenólicos e flavonóides, foram identificados pela primeira vez em ambos os extratos da planta medicinal Baccharis alnifolia. Os cromatogramas UHPLC-DAD revelaram a presença majoritária de ácido ferúlico e luteolina, ambos podendo ser responsáveis pela atividade antioxidante e citotóxica. Além disso, realizamos uma triagem preliminar da citotoxicidade em diferentes linhagens de células tumorais, descobrindo que esses extratos têm potencial citotóxico nas células renais.

Palavras-chave: antioxidante, Baccharis alnifolia, bioatividade, planta medicinal, UHPLC-DAD.

\section{INTRODUCTION}

The northern of Chile, ecoregion of Puna, presents unique characteristics and stretches out from southern-central Peru to northern Argentina and Chile with an altitude ranging from 3000 to 5000 meters above sea level. This region is characterized by low relative humidity, high solar radiation levels, lack of oxygen and a wide variation of temperature during the day and the night (CABRERA, 1968). In this habitat grow many vegetal products that have developed a great variety of bioactive compounds as an adaptation to environmental stress, including the biosynthesis of secondary metabolites with relevant pharmacological activities (TIMMERMANN \& HOFFMANN, 1985;
KLEIER \& LAMBRINOS, 2005). Vegetation is dominated by an alternation of grasses and shrubs that are used by the Andeans inhabitants as a source of food, medicine, forage, and building (TORRESCARRO et al., 2017). One of the most abundant shrubs is the Chilka, a plant known by this name for the communities of the Andes. This common name is attributed to several species belonging to the genus Baccharis (B. alnifolia Meyen \& Walp., B. boliviensis (Wedd.) Cabrera var. Boliviensis, B. salicifolia (Ruiz et Pav.) Pers., B. calliprinos Grise, and Lejia (or Lekia), identified as Baccharis antelices Phil. spp. santelices and B. tola Phil. spp. Tola (ORTIZ et al., 2019). For this research, we choose the Baccharis alnifolia Meyen \& Walp., because according to our 
knowledge, there is little or almost no information about this species (BELTRÁN et al., 2006). In Chile, it grows from 2800 to 3800 meters above sea level in rugged and flat areas of Precordillera. B. alnifolia serves occasional fodder when there is a shortage of food. Also, it serves to build roofs and as firewood. In traditional medicine, it is used to prepare poultices against blows, bruises and also against tonsillitis as infusion tea (GONZÁLEZ \& MOLINA, 2017). This research aimed to realize a comprehensive study about the antioxidant potential and anticancer potential screening of Baccharis alnifolia Meyen \& Walp in its leaves, as well as in its infusion.

\section{MATERIALS AND METHODS}

\section{Chemicals}

HPLC solvents and LC formic acid were from Merck (Santiago, Chile). HPLC standards, (kaempferol, quercetin, isorhamnetin, luteolin, naringenin, caffeic acid, vanillic acid, $p$-cumaric acid, ferulic acid; all standards with purity higher than $95 \%$ by HPLC) were purchased either from Sigma Aldrich (Saint Louis, Mo, USA). FolinCiocalteu's reagent, gallic acid, anhydrous sodium carbonate, aluminum chloride hexahydrate, sodium nitrate, sodium hydroxide, sodium acetate trihydrate, ferric chloride hexahydrate and ethanol absolute were obtained from Merck (Santiago, Chile). TPTZ (1,3,5-triphenyltetrazolium chloride), ABTS [2,2'-azinobis (3-ethylbenzothiazoline6-sulphonate)], potassium persulfate, Trolox (6-hydroxy-2, 5, 7,8-tetramethylchroman-2carboxylic acid), diethyl ether, hydrochloric acid, nitric acid, sulfuric acid, quercetin, and glacial acetic acid were supplied by Sigma-Aldrich (Santiago, Chile).

\section{Plant material}

Fresh aerial parts of $B$. alnifolia Meyen \& Walp. were collected in February 2018 from the Putre zone, (Andean Altiplano, northern Chile) (18¹2'21'S; 69³3'6”O) placed approx. 3652 m.a.s.l. Alicia Marticorena identified the plant. A voucher specimen No. 184925 was deposited in the Herbarium from the Botany Department of the Universidad de Concepción, Chile.

\section{Ethanolic extraction}

Dried and powdered aerial parts of $B$. alnifolia (1 g) were extracted with absolute ethanol for 30 minutes in the dark in an ultrasonic bath (100 $\mathrm{mL}$, three times) in order to obtain an extract for the
UHPLC, antioxidant and cytotoxic analyses. The extract was immediately concentrated under vacuum, and a resulting brown gum was obtained $(127 \mathrm{mg}$ ).

\section{Infusion extraction}

B. alnifolia infusion was prepared from the whole herb (stem and leaves), using $0.5 \mathrm{~g}$ of plant brewed for 5 minutes in $250 \mathrm{~mL}$ water at $100^{\circ} \mathrm{C}$. Infusion was left to cool at room temperature and tested for bioactive compounds on the same day. All measurements were performed in triplicate (LARRAZABAL et al., 2018).

\section{UHPLC-DAD instrument}

The Knauer Azura analytical UHPLC system is comprising of the Azura P 6.1 L pump, 3950 auto samplers, and Azura DAD 2.1 L diode array detector with high sensitivity Knauer. For the analysis $5 \mathrm{mg}$ of the resin, the extract was dissolved in $2 \mathrm{~mL}$ of methanol, filtered (PVDF filter) and $10 \mu \mathrm{L}$ was injected in the instrument.

\section{Liquid chromatography parameters.}

Liquid chromatography was performed using an UHPLC C18 column (Luna ${ }^{\circledR}, 100 \mathrm{~mm} \times 4.6$ $\mathrm{mm}, 3.0 \mu \mathrm{m}$, Phenomenex, Torrance, USA) operated at $25{ }^{\circ} \mathrm{C}$. The detection wavelengths were 254,280 , 330 and $354 \mathrm{~nm}$, and DAD was recorded from 200 to $800 \mathrm{~nm}$ for peak characterization. Mobile phases were $1 \%$ formic aqueous solution (A) and acetonitrile (B). The gradient program time (min, \% B) was: $(0.00,5) ;(3.00,30) ;(20.00,70) ;(22.00,5)$; and 10 minutes for column equilibration before each

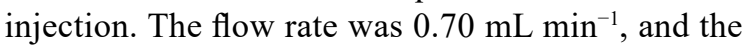
injection volume was $10 \mu \mathrm{L}$. Standards and resin extract dissolved in methanol were kept at $10^{\circ} \mathrm{C}$ during storage in the auto sampler.

\section{Total polyphenol and flavonoid contents}

Total polyphenolic contents (TPC) were determined by the Folin-Ciocalteau method as reported (PARRA et al., 2017). Determination of total flavonoid content (TFC) of the resin was performed as previously described (PARRA et al., 2017).

\section{Antioxidant assays}

To measure the antioxidant activity of nine plants, we used the FRAP, TEAC, and ORAC assays. Every analysis was performed in BioTek Synergy HTX Multi-Mode Microplate Reader (Winooski, VT, USA) using 96-well microplates. For all antioxidant assays, a standard curve of Trolox was used, and results were expressed as Trolox equivalents gram dry weight (mmol TE/g of DW). The FRAP and TEAC assays 
were performed according to PARRA et al. (2017), with modifications. For the FRAP assay, $25 \mu \mathrm{L}$ of appropriately diluted extract sample was mixed on a 96well microplate with $175 \mu \mathrm{L}$ of freshly prepared FRAP reagent. After the mixture, the sample was incubated for $15 \mathrm{~min}$ at $37{ }^{\circ} \mathrm{C}$, and then the absorbance of the ferrous complex was recorded at $593 \mathrm{~nm}$. For TEAC assay, 20 $\mu \mathrm{L}$ of extract was added to $200 \mu \mathrm{L}$ of diluted $\mathrm{ABTS}^{++}$ solution $\left(\mathrm{A}_{734 \mathrm{~nm}}=0.700 \pm 0.002\right)$. The reactive mixture was incubated for $7 \mathrm{~min}$ at $25^{\circ} \mathrm{C}$, and the absorbance was immediately recorded at $734 \mathrm{~nm}$. The ORAC assay was performed according to Ou with some modifications (OU et al., 2002). Fluorescein (8 nM), AAPH (75 $\mathrm{mM}$ ) and dilution of sample extract were prepared in phosphate buffer solution (75 mM, pH 7.0). Extract sample $(25 \mu \mathrm{L})$ was mixed with $100 \mu \mathrm{L}$ of fluorescein in a Nunc 96 Microwell black plates (Thermo Scientific, UK) and incubated at $37{ }^{\circ} \mathrm{C}$ for $30 \mathrm{~min}$. Then, $75 \mu \mathrm{L}$ of AAPH was added, and the fluorescein intensity was measured every minute for $120 \mathrm{~min}$ at excitation and emission wavelengths of 485 and $520 \mathrm{~nm}$, respectively. The final ORAC values were calculated using the area under the curve (AUC) and the regression equation between Trolox and the net AUC.

\section{Cell cultures}

Six cells lines were used, A549 (Human lung carcinoma), B-16 (murine melanoma), Caco-2 (human colorectal adenocarcinoma), HEK-293 (Human embryo kidney), HepG2 (liver carcinoma) and MCF7 (Human breast adenocarcinoma). The MCF7 was cultured in MEM medium supplemented with $100 \mathrm{U} / \mathrm{mL}$ penicillin, $100 \mathrm{mg} / \mathrm{mL}$ streptomycin, $2.5 \mathrm{mg} / \mathrm{mL}$ amphotericin B (all from Corning, Tewksbury, MA, USA), 10\% fetal bovine serum (FBS) (Hyclone, South Logan, Utah, U.S) and $10 \mathrm{mg} / \mathrm{mL}$ recombinant human insulin (GIBCO, Life Technologies, Grand Island, NY, USA). A549, Caco-2, HepG2, HEK-293, and B-16 were cultured in DMEM medium supplemented with 10\% FBS and $100 \mathrm{U} / \mathrm{mL}$ penicillin, $100 \mathrm{mg} / \mathrm{mL}$ streptomycin, 2.5 $\mathrm{mg} / \mathrm{mL}$ amphotericin B (all from Corning, Tewksbury, MA, USA). Incubation conditions were established at $37^{\circ} \mathrm{C}$, whole humid atmosphere, $5 \% \mathrm{CO}_{2}$ and $95 \% \mathrm{O}_{2}$. Cells were seeded for 1 day before exposure in a 96-well format in sextuplicate, for A549, Caco-2, MCF7, and HepG2 10,000 cells per well were seeded, and 20,000 cells/well for HEK-293 and B-16 cell lines. After this incubation period, the culture medium was discarded and washed with sterile DPBS.

\section{In vitro cytotoxic screening}

To measure cytotoxic effects, we assessed cell viability using MTT assay. Cells in the DMEM medium without serum were exposed to ethanolic extract and infusion (10 and $100 \mu \mathrm{g} / \mathrm{mL})$ for a period of $24 \mathrm{hrs}$. Culture medium with extract treatments was discarded and replaced with $200 \mu \mathrm{l}$ MTT medium and incubated for $2.5 \mathrm{~h}$ at $37{ }^{\circ} \mathrm{C}$ and $5 \% \mathrm{CO}_{2}$. An amount of $200 \mu \mathrm{L}$ of DMSO was used for solubilizing the formazan crystals. The absorbance was measured with a TECAN Infinite pro 200 plate reader at $560 \mathrm{~nm}$. The viability percentage was calculated against a non-drug treated control (designated $100 \%$ viability) considered as a control vehicle $(\leq 0.5 \%$ DMSO). For background absorption, some wells remained cell-free with DMSO as a blank control. The experimental data were expressed as means $\pm \mathrm{SD}$; the comparisons were made between controls and treated cultures using a one-way ANOVA followed by Dunnett's post-hoc test for multiple comparisons. $\mathrm{p}<0.05$ was considered to indicate a statistically significant difference between values.

\section{RESULTS AND DISCUSSION}

Due to the scarce information available for this specie, we considered it very important to determine some chemical parameters that can give an orientation of the antioxidant potential related to the consumption of this medicinal plant. As outlined in the introduction there are no available data on bioactive compounds in medicinal plants like B. alnifolia. The first goal of our study was to establish a comprehensive overview of the antioxidant properties of leaves and herbal infusion of this species. For this, it assessed the total polyphenol content (TPC) and total flavonoid content (TFC) and compared to other plants. Moreover, Ferric reducing antioxidant power (FRAP), Oxygen Radical Absorbance Capacity (ORAC) and Trolox equivalent antioxidant capacity (TEAC) assay were used to evaluate the antioxidant capacity of $B$. alnifolia (Table 1). These methods are simple and widely used for the evaluation of antioxidant capacity (LÓPEZALARCÓN \& DENICOLA, 2013). Thus, the TPC values of this plant, $4.42 \pm 0.06 \mathrm{mg} \mathrm{GAE} / \mathrm{g}$ dry weight, were close to some fruits, grains, and seeds (CHIRINOS et al., 2013), but lower than other Baccharis reports (SIMIRGIOTIS et al., 2016). While the infusion sample (35.86 $\pm 0.58 \mathrm{mg}$ $\mathrm{GAE} / \mathrm{L}$ ), also showed values close to those reported for the aerial parts of Baccharis tola infusion (ROJO et al., 2009). The FRAP value for the ethanolic extract was $13.29 \pm 2.78 \mu \mathrm{mol}$ Trolox equivalents $/ \mathrm{g}$ of dry weight, is higher than that reported for some vegetables, legumes, and cereals that are between 2.2 and $10.3 \mu$ mol Trolox equivalents/g dry matter edible part (SAURA-CALIXTO \& GOÑI, 2006). Whereas the infusion of B. alnifolia (619 $\pm 8.58 \mu \mathrm{mol}$ Trolox equivalents/L) was much higher than the infusion of Acantholippia deserticola (Phil.) infusion 
Table 1- Phenolic compounds, total flavonoids and antioxidant activities of ethanolic extract Baccharis alnifolia from northern Chile.

\begin{tabular}{lcccccc}
\hline B. alnifolia & Yield $^{\mathrm{a}}$ & TPC & TFC & FRAP & TEAC & ORAC \\
\hline Aerial parts & 12.7 & $4.42 \pm 0.06^{\mathrm{b}}$ & $1.24 \pm 0.24^{\mathrm{d}}$ & $13.29 \pm 0.61^{\mathrm{f}}$ & $6.19 \pm 0.03^{\mathrm{f}}$ & $170.64 \pm 0.01^{\mathrm{f}}$ \\
Infusion & 10.3 & $35.86 \pm 0.60^{\mathrm{c}}$ & $8.05 \pm 0.30^{\mathrm{e}}$ & $618.77 \pm 8.80^{\mathrm{g}}$ & $546.26 \pm 11.55^{\mathrm{g}}$ & $599.52 \pm 0.15^{\mathrm{g}}$ \\
\hline
\end{tabular}

The values were expressed as mean \pm SD $(n=3)$;

${ }^{\text {a }}$ Expressed as percentage

${ }^{\mathrm{b}}$ Expressed as mg of gallic acid per gram of dry weight

${ }^{c}$ Expressed as mg of gallic acid per liter of infusion

${ }^{d}$ Expressed as mg of quecentine per gram of dry weight

${ }^{\mathrm{e}}$ Expressed as mg of quecentine per liter of infusion

${ }^{\mathrm{f}}$ Expressed as $\mu \mathrm{mol}$ of trolox per gram of dry weight

${ }^{\mathrm{g}}$ Expressed as $\mu \mathrm{mol}$ of trolox per liter of infusion

$(69.2 \pm 0.04 \mu \mathrm{mol}$ Trolox equivalents/L), mint and chamomile commercially available (LARRAZABAL et al., 2018). The TEAC value (6.19 $\pm 0.03 \mu \mathrm{mol}$ Trolox/g dry weight) were close to reported for different medicinal plants and were between 6.15 to $7.81 \mu \mathrm{mol}$ Trolox/g dry weight (GAN et al., 2010). Moreover, the TEAC values for infusion sample also showed values close to those reported for Acantholippia deserticola (Phil.) infusion (LARRAZABAL et al., 2018), but it was lower to obtain Baccharis tola infusion and other plants from South American Andes (ROJO et al., 2009). The ORAC value for ethanolic extract was $170.64 \pm 0.01 \mu \mathrm{mol}$ Trolox/g dry weight, and its value for herbal infusion was $599.52 \pm 0.15 \mu \mathrm{mol}$ Trolox/L is a little higher than Aloysia triphylla infusion (ABDERRAHIM et al., 2011). Furthermore, we have determined some metabolites for ethanolic extract and infusion of $B$. alnifolia, among them four phenolic acids and three flavonoids, they were identified by UHPLC (Figure 1). The examination of the ethanolic extract chromatogram revealed the presence of caffeic acid (peak 4); vanillic acid (peak 5); $p$-cumaric acid (peak 8); ferulic acid (peak 9). Also identified one flavone, one flavanone, and one flavonol: luteolin (peak 14); naringenin (peak 18) and kaempferol (peak 19), respectively. All compounds

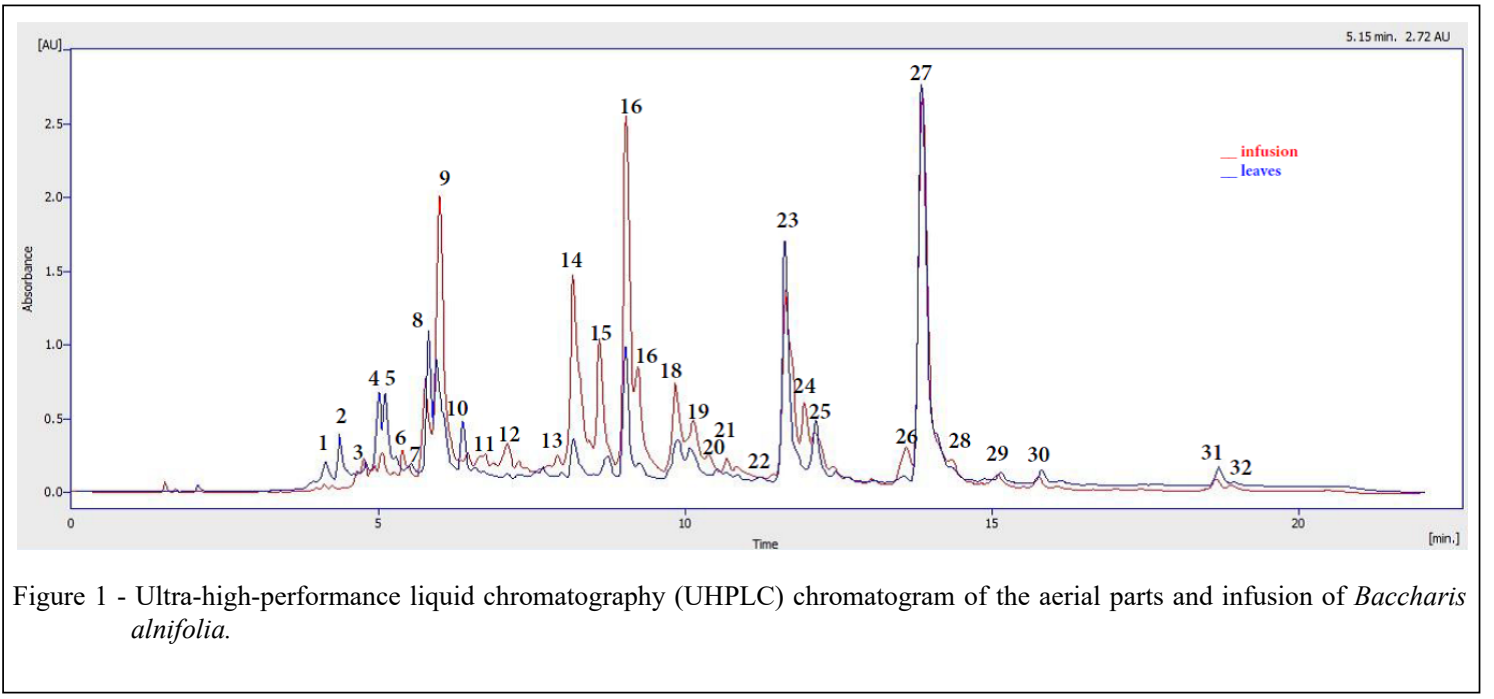

Ciência Rural, v.49, n.10, 2019. 
Table 2 - Identified Compounds in Baccharis alnifolia ethanolic extract by UHPLC.

\begin{tabular}{|c|c|c|c|c|c|}
\hline peak & Identified compound ${ }^{*}$ & Type of compound & $t_{R}(\min )$. & $\begin{array}{c}\text { Aerial parts } \\
\text { (mg/g DW) }\end{array}$ & $\begin{array}{c}\text { Infusion }^{*} \\
(\mathrm{mg} / \mathrm{g} \text { DW })\end{array}$ \\
\hline 4 & caffeic acid & phenolic acid & 4.92 & $1.48 \pm 0.02$ & $0.26 \pm 0.03$ \\
\hline 5 & vanillic acid & phenolic acid & 5.03 & $3.13 \pm 0.05$ & $1.47 \pm 0.09$ \\
\hline 8 & $p$-cumaric acid & phenolic acid & 5.82 & $0.76 \pm 0.02$ & $1.00 \pm 0.01$ \\
\hline 9 & ferulic acid & phenolic acid & 5.98 & $12.89 \pm 0.76$ & $64.63 \pm 0.72$ \\
\hline 14 & luteolin & flavone & 8.10 & $2.91 \pm 0.12$ & $16.53 \pm 0.08$ \\
\hline 18 & naringenin & flavanone & 9.79 & $1.29 \pm 0.03$ & $2.95 \pm 0.09$ \\
\hline 19 & kaempferol & flavonol & 10.05 & $1.26 \pm 0.06$ & $2.41 \pm 0.10$ \\
\hline
\end{tabular}

${ }^{*}$ Analyses confirmed by comparing with pure standards. ${ }^{* *}$ The values were expressed as mean $\pm \operatorname{SD}(\mathrm{n}=3)$.

were reported and identified by co-elution with an authentic compound. For the infusion extract, the same compounds of the ethanolic extract were identified but with change in their concentrations (Table 2). When we analyzed the chromatograms, we observed that the caffeic and vanillic acids were reported in a lower amount than in ethanolic extract. However, the ferulic acid and luteolin increased their concentration by five times compared to the ethanol extract (Table 2). The ferulic acid increase could be related with antioxidant and cytotoxic activity of Chilka infusion (JANICKE et al., 2011).

In contrast, the increase of the signal of luteolin in the infusion could contribute to reducing inflammation, and it acts as potent neuroprotective (NABAVI et al., 2015). Also, we observed the appearance of new signals (peaks 11, $12,16,24$ and 26) in the aqueous extraction. The increase exponential of the ferulic acid signal in $B$. alnifolia infusion also could be related to the antiinflammatory effect of this plant (ZHU et al., 2014). Other compounds that have increased their signal force are the peaks $9,14,15$ and 16 , it being the last one of the major compounds in the chromatogram (Figure 1). Compounds extracted from the infusion were identified by spiking experiment with standards. To improve the knowledge about this species, we realize a preliminary cytotoxic screening was made over six cell lines at two concentrations (10 and 100 $\mathrm{ug} / \mathrm{mL}$ ) (Table 3). Neither the ethanolic extract or infusion presented cell viability lesser than $\leq 50 \%$ at $10 \mu \mathrm{g} / \mathrm{mL}$ in any cell line at $24 \mathrm{~h}$ exposure time, with only a slight activity of the infusion on HepG2 cells $(75.1 \pm 2.9 \mu \mathrm{g} / \mathrm{mL})$, meanwhile at $100 \mu \mathrm{g} /$ $\mathrm{mL}$ they showed activity over most of all cell lines, showing high activity at higher concentration. For

Table 3 - Screening of cytotoxic of Baccharis alnifolia leaves ethanolic extract and infusion.

\begin{tabular}{|c|c|c|c|c|}
\hline \multirow{2}{*}{$\begin{array}{l}\text { Cells } \\
\mathrm{GI}_{50}\end{array}$} & \multicolumn{2}{|c|}{ 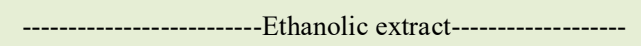 } & \multicolumn{2}{|c|}{ 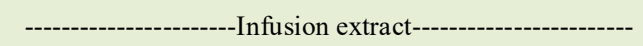 } \\
\hline & $10 \mathrm{ug} / \mathrm{mL}$ & $100 \mathrm{ug} / \mathrm{mL}$ & $10 \mathrm{ug} / \mathrm{mL}$ & $100 \mathrm{ug} / \mathrm{mL}$ \\
\hline $\mathrm{Caco} 2$ & $91.6 \pm 19.5$ & $2.4 \pm 2.7$ & $86.1 \pm 15.6$ & $2.0 \pm 1.6$ \\
\hline HepG-2 & $81.4 \pm 2.6$ & $2.1 \pm 0.9$ & $75.1 \pm 2.9$ & $2.1 \pm 0.4$ \\
\hline MCF7 & $105.3 \pm 10.4$ & $78.1 \pm 8.4$ & $97.4 \pm 9.5$ & $66.5 \pm 6.2$ \\
\hline A549 & $91.0 \pm 4.5$ & $2.0 \pm 1.5$ & $96.1 \pm 5.4$ & $3.1 \pm 1.8$ \\
\hline HEK 293 & $79.0 \pm 20.2$ & $0.8 \pm 0.4$ & $84.9 \pm 15.3$ & $0.7 \pm 0.4$ \\
\hline B16 & $84.0 \pm 6.9$ & $2.3 \pm 1.0$ & $77.5 \pm 9.5$ & $3.0 \pm 1.6$ \\
\hline
\end{tabular}

${ }^{*}$ The values were expressed as mean $\pm \operatorname{SD}(n=6)$. 
MCF7 cells was less sensitive to both extracts not presenting cell viability lesser than $50 \%$. In conclusion, using UHPLC we have identified seven phenolic compounds in the ethanolic extract and infusion of Baccharis alnifolia, as far as we know, is reported for the first time for this plant. Moreover, we determined the total polyphenol, flavonoids content, the antioxidant capacity and a first glance of the cytotoxic activity for this species and giving a first approximation of the potential of its infusion.

\section{ACKNOWLEDGMENTS}

This study was supported by Comisión Nacional de Investigación Científica y Tecnológica (CONICYT), (Grant R16F20001).

\section{DECLARATION OF CONFLICT OF INTEREST}

The authors declare no conflict of interest. The founding sponsors had no role in the design of the study; in the collection, analyses, or interpretation of data; in the writing of the manuscript, and in the decision to publish the results.

\section{AUTHORS CONTRIBUTIONS}

All authors contributed equally for the conception and writing of the manuscript. All authors critically revised the manuscript and approved the final version.

\section{REFERENCES}

ABDERRAHIM, F., et al. The antioxidant activity and thermal stability of lemon verbena (Aloysia triphylla) infusion. Journal of medicinal food, v.14, n.5, p.517-527. 2011. Available from: $<$ https://doi.org/10.1089/jmf.2010.0102>. Accessed: Mar. 20, 2019. doi: 10.1089/jmf.2010.0102.

BELtRÁN, H., et al. Asteraceae endémicas del Perú. Revista Peruana de Biología, v.13, n.2, p.64-164. 2006. Available from: $\quad<$ http://www.scielo.org.pe/scielo.php?pid=S1727$99332006000200016 \& \mathrm{script}=\mathrm{sci}$ arttext\&tlng $=\mathrm{pt}>$. Accessed: Mar. 25, 2019.

CABRERA, A. L. Ecología vegetal de la puna. Ferd. Dümmers Verlag. 1968

CHIRINOS, R., et al. Phenolic compound contents and antioxidant activity in plants with nutritional and/or medicinal properties from the Peruvian Andean region. Industrial Crops and Products, v.47, p.145-152. 2013. Available from: <https://doi.org/10.1016/j. indcrop.2013.02.025>. Accessed: Mar. 25, 2019. doi: 10.1016/j. indcrop.2013.02.025.

GAN, R.-Y., et al. Antioxidant activity and total phenolic content of medicinal plants associated with prevention and treatment of cardiovascular and cerebrovascular diseases. Journal of Medicinal
Plants Research, v.4, n.22, p.2438-2444. 2010. Available from: $<$ https://doi.org/10.5897/JMPR10.581>. Accessed: Mar. 29, 2019. doi: $10.5897 / J M P R 10.581$.

GONZÁLEZ, J. S.; J. J. MOLINA. Flora nativa de la región de Arica y Parinacota. 2017. Ediciones Universidad de Tarapacá. Arica, Chile. 233 pp.

JANICKE, B., et al. The antiproliferative effect of dietary fiber phenolic compounds ferulic acid and p-coumaric acid on the cell cycle of Caco-2 cells. Nutrition and cancer, v.63, n.4, p.611-622. 2011. Available from: <https://doi.org/10.10 80/01635581.2011.538486>. Accessed: Mar. 29, 2019. doi: $10.1080 / 01635581.2011 .538486$

KLEIER, C.; J. G. LAMBRINOS. The importance of nurse associations for three tropical alpine life forms. Arctic, Antarctic, and Alpine Research, v.37, n.3, p.331-336. 2005. Available from: $\quad<$ https://www.tandfonline.com/doi/full/10.1657/15230430(2005)037\%5B0331:TIONAF\%5D2.0.CO;2>. Accessed: Mar. 29, 2019. doi: 10.1657/1523-0430(2005)037[0331:TIONA $\mathrm{F}] 2.0 . \mathrm{CO} ; 2$.

LARRAZABAL, M. J., et al. Effect of brewing conditions on pigments and total polyphenols content and biological activities of the Acantholippia deserticola (Phil.) infusion. CyTA-Journal of Food, v.16, n.1, p.588-595. 2018. Available from: <https://doi.org /10.1080/19476337.2018.1441189>. Accessed: Apr. 09, 2019. doi: $10.1080 / 19476337.2018 .1441189$.

LÓPEZ-ALARCÓN, C.; A. DENICOLA. Evaluating the antioxidant capacity of natural products: A review on chemical and cellular-based assays. Analytica Chimica Acta, v.763, p.1-10. 2013. Available from: <https://doi.org/10.1016/j.aca.2012.11.051>. Accessed: Apr. 09, 2019. doi: 10.1016/j.aca.2012.11.051.

NABAVI, S. F., et al. Luteolin as an anti-inflammatory and neuroprotective agent: A brief review. Brain research bulletin, v.119, p.1-11. 2015. Available from: <https://doi.org/10.1016/j. brainresbull.2015.09.002>. Accessed: Mar. 29, 2019. doi: 10.1016/j.brainresbull.2015.09.002.

ORTIZ, S., et al. Bioguided identification of triterpenoids and neolignans as bioactive compounds from anti-infectious medicinal plants of the Taira Atacama's community (Calama, Chile). Journal of ethnopharmacology, v.231, p.217-229. 2019. Available from: $<$ https://doi.org/10.1016/j.jep.2018.10.029>. Accessed: Apr. 15, 2019. doi: 10.1016/j.jep.2018.10.029.

OU, B., et al. Analysis of antioxidant activities of common vegetables employing oxygen radical absorbance capacity (ORAC) and ferric reducing antioxidant power (FRAP) assays: a comparative study. Journal of agricultural and food chemistry, v.50, n.11, p.31223128. 2002. Available from: <https://doi.org/10.1021/jf0116606>. Accessed: Nov. 06, 2015. doi: 10.1021/jf0116606.

PARRA, C., et al. Nutritional composition, antioxidant activity and isolation of scopoletin from Senecio nutans: support of ancestral and new uses. Natural Product Research, p.719-722. 2017. Available from: $<$ https://doi.org/10.1080/14786419.2017.1335726 >. Accessed: Jul. 15, 2018. doi: 10.1080/14786419.2017.1335726. 
ROJO, L. E., et al. Antioxidant capacity and polyphenolic content of twelve traditionally used herbal medicinal infusions from the South American Andes. Boletín Latinoamericano y del Caribe de Plantas Medicinales y Aromáticas, v.8, n.6, p.498-508. 2009. Available from: <https://www.blacpma.usach.cl/sites/blacpma/ files/008-006.pdf>. Accessed: May, 05, 2018.

SAURA-CALIXTO, F.; I. GOÑI. Antioxidant capacity of the Spanish Mediterranean diet. Food chemistry, v.94, n.3, p.442-447. 2006. Available from: <https://doi.org/10.1016/j. foodchem.2004.11.033>. Accessed: May, 20, 2019. doi: 10.1016/j. foodchem.2004.11.033.

SIMIRGIOTIS, M. J., et al. High resolution metabolite fingerprinting of the resin of Baccharis tola Phil. from the Atacama Desert and its antioxidant capacities. Industrial Crops and Products, v.94, p.368-375. 2016. Available from: <https://doi. org/10.1016/j.indcrop.2016.08.037>. Accessed: May, 22, 2019. doi: $10.1016 /$ j.indcrop.2016.08.037.
TIMMERMANN, B. N.; J. J. HOFFMANN. Resins from Grindelia: a model for renewable resources in arid environments. In: (Ed.). Plants for arid lands: Springer, 1985. Resins from Grindelia: a model for renewable resources in arid environments, p.357-368

TORRES-CARRO, R., et al. Inhibition of pro-inflammatory enzymes by medicinal plants from the Argentinean highlands (Puna). Journal of ethnopharmacology, v.205, p.57-68. 2017. Available from: <https://doi.org/10.1016/j.jep.2017.04.013>. Accessed: May, 22, 2019. doi: 10.1016/j.jep.2017.04.013.

ZHU, H., et al. Anti-inflammatory effects of the bioactive compound ferulic acid contained in oldenlandia diffusa on collageninduced arthritis in rats. Evidence-Based Complementary and Alternative Medicine, v.2014. 2014. Available from: <http:// dx.doi.org/10.1155/2014/573801>. Accessed: May, 29, 2019. doi: $10.1155 / 2014 / 573801$. 